\title{
Peramalan Curah Hujan Sebagai Pendukung Kalender Tanam Padi di Pos Kedungadem Bojonegoro Menggunakan ARIMA, Support Vector Regression dan Genetic Algorithm-SVR
}

\author{
Kiki Wulan Suci dan Irhamah \\ Jurusan Statistika, Fakultas Matematika dan Ilmu Pengetahuan Alam, Institut Teknologi Sepuluh Nopember (ITS) \\ Jl. Arief Rahman Hakim, Surabaya 60111 Indonesia \\ e-mail : kwulansuci@gmail.com dan irhamahn@gmail.com
}

\begin{abstract}
Abstrak-Kabupaten Bojonegoro dikenal sebagai lum-bung padi di Jawa Timur. Sebanyak 33,31\% lahan Bojonegoro digunakan sebagai lahan sawah. Pada beberapa tahun ter-akhir produksi padi Kabupaten Bojonegoro mengalami fluk-tuasi yang salah satunya disebabkan oleh iklim ekstrem. Ik-lim ekstrem dapat mengakibatkan musim kemarau panjang serta adanya hujan ekstrem yang mengakibatkan petani me-ngalami kerugian. Oleh karena itu, keberhasilan produksi padi sangat bergantung pada informasi mengenai data curah hujan yang tersusun dalam kalender tanam. Dalam penelitian ini dilakukan peramalan curah hujan dasarian di Pos Kedung-adem menggunakan metode ARIMA, Support Vector Regres-sion (SVR) dan Genetic AlgorithmSupport Vector Regression (GA-SVR). Berdasarkan hasil analisis metode GA-SVR meng-hasilkan peramalan yang lebih akurat yang ditunjukkan oleh nilai RMSE dan SMAPE yang lebih kecil dibandingkan me-tode lain. Hasil kalender tanam padi berdasarkan hasil fore-cast pada bulan Juli 2016-Desember 2016 menunjukkan bah-wa kebutuhan air untuk penanaman padi sawah tidak dapat tercukupi, dimana hasil forecast menunjukkan rata-rata curah hujan kurang dari $145 \mathrm{~mm}$. Petani dapat mengganti dengan menanam palawija yang membutuhkan sedikit air. Jika petani tetap melakukan tanam padi, maka petani dan pemerintah harus memastikan tersedianya cadangan air dengan meng-gunakan sistem pengairan dan tidak mengandalkan pada tu-runnya hujan.
\end{abstract}

Kata Kunci-ARIMA, Curah Hujan, Genetic Algorithm, Support Vector Regression (SVR).

\section{PENDAHULUAN}

$\mathrm{K}$ ABUPATEN Bojonegoro dikenal sebagai lumbung padi di Jawa Timur. Sebanyak 33,31\% lahan Bojonegoro diguna-kan sebagai lahan sawah [1]. Pada beberapa tahun terakhir produksi padi Kabupaten Bojonegoro mengalami fluktuasi. Salah satu penyebab fluktuasi produksi padi adalah iklim ekstrem. Iklim ekstrem dapat mengakibatkan musim kema-rau yang panjang serta adanya hujan ekstrem yang mengakibatkan petani mengalami kerugian [2].

Penelitian ini mengambil studi kasus di wilayah se-latan Bojonegoro yaitu di pos pengamatan curah hujan $\mathrm{Ke}$ dungadem. Kedungadem merupakan kecamatan di Bojonegoro Selatan dengan tipe sawah dominan adalah sawah tadah hujan yang mengandalkan turunnya air hujan dalam produksi padi. Pada kecamatan Kedungadem prosentase luas sawah tadah hujan mencapai $98 \%$ dari total lahan sa-wah [3]. Oleh karena itu, keberhasilan produksi padi sangat bergantung pada informasi mengenai data curah hujan. Peramalan curah hujan yang akurat akan dapat mengurangi kerugian petani akibat kegagalan panen.

Peramalan curah hujan menggunakan ARIMA telah beberapa dilakukan. Namun, penggunaan ARIMA sering-kali belum mampu memberikan residual yang berdistribusi normal, belum mampu mengakomodasi adanya data outlier serta tidak mampu memodelkan time series yang nonlinier [4]. Padahal data curah hujan seringkali menghasilkan data yang non linier. Oleh karena itu, akan digunakan digunakan metode Support Vector Regression (SVR). SVR dapat me-nangkap kasus non linieritas dengan menambahkan fungsi kernel. Pada penelitian ini digunakan fungsi kernel Radial Basis Function (RBF) yang sering digunakan dan meng-hasilkan kinerja yang lebih bagus [5]. Metode SVR dapat mengatasi kasus overfitting serta SVR adalah metode yang tidak memerlukan asumsi. Metode SVR juga dapat mem-berikan hasil yang baik walaupun hanya dengan data yang sedikit [6] [7]. Salah satu permasalahan yang ketika meng-gunakan SVR dengan menggunakan algoritma grid search adalah penentuan parameter model yang optimal, dika-renakan grid search hanya memilih parameter yang optimal pada range parameter yang ditetapkan. Oleh karena itu, pe-nelitian ini akan digunakan Genetic Algorithm (GA) untuk optimasi nilai parameter SVR dengan harapan dapat menghasilkan nilai akurasi yang lebih bagus.

Penelitian dengan menggunakan metode SVR dan GA pernah dilakukan oleh Msiza, Nelwamondo dan Marwala (2008) untuk meramalkan permintaan air dengan hasil penelitian yaitu hasil prediksi yang dihasilkan oleh ANN dan SVR memberikan hasil error yang lebih kecil [8]. Tahun $2011 \mathrm{Gu}$, Zhu dan Jiang menggunakan GA-SVR untuk me-ramalkan harga perabotan rumah dimana metode GA-SVR menghasilkan peramalan yang lebih akurat dibandingkan menggunakan grid algorithm [9]. Penelitian kali ini akan menerapkan metode ARIMA, SVR dan GA-SVR untuk me-ramalkan curah hujan di Kabupaten Bojonegoro. Kriteria perbandingan akurasi ramalan yang digunakan adalah nilai RMSE dan SMAPE. Berdasarkan pada hasil peramalan periode selanjutnya dengan metode terbaik, akan dibuat susunan kalender tanam padi untuk tipe sawah tadah hujan. 


\section{TINJAUAN PUSTAKA}

\section{A. Autoregressive Moving Average (ARIMA)}

Metode peramalan yang biasanya sangat baik digu-nakan untuk melakukan peramalan jangka pendek adalah metode ARIMA. Secara umum model ARIMA $(p, d, q)$ di-tulis sebagai berikut [10].

$$
\emptyset_{p}(B)(1-B)^{d} Y_{t}=\theta_{0}+\theta_{q}(B) a_{t}
$$

Sebelum menggunakan ARIMA terdapat asumsi yang harus dipenuhi yaitu data harus stasioner terhadap mean dan varians [10] [11]. Setelah data dapat memenuhi asumsi tersebut maka dilakukan identifikasi model ARIMA dilakukan dengan melihat plot ACF dan PACF [10].

Tahapan selanjutnya adalah melakukan estimasi parameter. Dalam penelitian ini, digunakan metode estimasi parameter Conditional Least Square (CLS). Kemudian di-lakukan uji signifikansi parameter dengan menggunakan uji $t$ [12], jika parameter tidak signifikan maka dilakukan iden-tifikasi model ARIMA kembali. Setelah didapatkan para-meter yang signifikan, kemudian dilakukan pengujian asu-msi residual yaitu white noise dan distribusi normal. Pe-menuhan asumsi residual yang white noise menggunakan uji L-jung Box dan pemenuhan asumsi normalitas residual menggunakan uji Kolmogorov-Smirnov [10] [13].

\section{B. Support Vector Regression (SVR)}

SVR merupakan bagian dari Supporrt Vector Machine (SVM) yang diperkenalkan oleh Vapnik (1995) yang digunakan untuk kasus regresi dan prediksi. Konsep SVR didasarkan pada pada risk minimization, yaitu mengestimasi suatu fungsi dengan cara meminimalkan batas atas dari generalization error, sehingga SVR mampu mengatasi overfitting [7]. Pada kasus nonlinier, fungsi regresi setelah transformasi menjadi seperti berikut:

$$
f(x)=w . \Phi(x)+b
$$

Dengan $w$ merupakan vector pembobot, $\Phi(x)$ merupakan fungsi yang memetakan $\mathrm{x}$ dalam suatu dimensi dan $b$ merupakan bias. Untuk mengevaluasi seberapa baik fungsi regresi, maka digunakan fungsi $\varepsilon$-insetive loss sebagai berikut.

$$
L_{\varepsilon}(y, f(x))=\left\{\begin{array}{c}
0 \text { untuk }|y-f(x)| \leq \varepsilon \\
|y-f(x)|-\varepsilon \text { dan sebaliknya }
\end{array}\right.
$$

Fungsi $\varepsilon$-insetive loss digunakan untuk mengukur risiko empiris, risiko empiris diukur berdasarkan persamaan (3), selisih output/ target dengan hasil estimasi. Oleh karena itu parameter $\varepsilon$ harus diatur untuk meminimalisir risiko em-piris. Disamping itu, juga harus meminimalisir norma Euc-lidean dari beban yang linier $\|w\|$ yang mana berhubungan dengan kemampuan generalisasi dari model SVR yang di training [6], sehingga permasalahan regresi dapat dinya-takan seperti masalah optimasi quadratik berikut ini:

$$
\begin{gathered}
L(w, \xi)=\frac{1}{2}\|w\|^{2}+C\left[\sum_{i=1}^{n}\left(\xi_{2 i}+\xi_{2 i}{ }^{\prime}\right)\right], c>0 \\
\text { subject to }\left\{\begin{array}{c}
y_{i}-w * \Phi\left(\boldsymbol{x}_{\boldsymbol{i}}\right)-b \leq \varepsilon+\xi_{i} \\
w * \boldsymbol{\Phi}\left(\boldsymbol{x}_{\boldsymbol{i}}\right)+b-y_{i} \leq \varepsilon+\xi_{i}{ }^{*} \\
\Phi_{i}, \xi_{i}{ }^{*} \geq 0
\end{array}\right.
\end{gathered}
$$

Koefisien $C$ menyatakan penalti yang mendeterminasikan trade-off antara keempirisan dengan kesalahan generalisasi, sehingga besarnya nilai $C$ tersebut perlu diatur [6]. Untuk menyelesaikan permasalahan pada optimasi quadratik pada persamaan (4), dapat menggunakan dual Lagrangian:

$$
f\left(x_{i}\right)=\left(\boldsymbol{w} \boldsymbol{\Phi}\left(\boldsymbol{x}_{\boldsymbol{i}}\right)+b\right)=\sum_{j=1}^{n} \alpha_{i} K\left(x_{i}, x_{j}\right)+b
$$

dimana $K\left(x_{i}, x_{j}\right)$ merupakan fungsi kernel. Jika fungsi ker-nel yang digunakan Radial Basis Function (RBF) maka per-lu mengatur parameter $\gamma$ sebagai berikut.

$$
K\left(x_{i}, x_{j}\right)=\exp \left(-\gamma\left\|x_{i}-x_{j}\right\|^{2}\right)
$$

Berdasarkan uraian mengenai SVR dapat dilihat bahwa terdapat tiga parameter yaitu $C, \varepsilon, \gamma$ dan fungsi kernel sangat penting dalam menentukan tingkat keakuratan dari prediksi.

\section{Genetic Algorithm (GA)}

Genetic Algorithm (GA) pertama kali dikembangkan oleh John Holland dari Universitas Michigan tahun 1975. GA adalah sebuah algoritma optimasi metaheuristik yang berdasarkan populasi solusi dan menggunakan mekanisme spesifik yang terinspirasi dari evolusi secara biologi seperti individu (kromosom), reproduksi, mutasi, rekombinasi, se-leksi, ketahanan fitness [14].

Sebuah solusi yang dibangkitkan dalam GA disebut kromosom, sedangkan kumpulan kromosom-kromosom disebut populasi. Berikut ilustrasi kromosom dengan tiga gen pada metode SVR dengan fungsi kernel RBF.

\begin{tabular}{l|r|r|l|}
\cline { 2 - 4 } Parameter & Cost & $\gamma$ & $\varepsilon$ \\
\cline { 2 - 4 } & 9,01 & 0,05 & 1,01 \\
\hline
\end{tabular}

Gambar 1. Ilustrasi Kromosom dengan Tiga Gen

Fitness individu dalam Genetic Algorithm adalah nilai fungsi objektif untuk fenotipe. Nilai fitness tidak hanya menunjukkan bagaimana solusi yang baik, tetapi juga berhubungan dengan seberapa dekat kromosom pada solusi optimum. Nilai fitness yang sering digunakan adalah RMSE [15]. [15].

Berikut adalah beberapa proses dalam Genetic Algorithm

1. Seleksi adalah suatu proses untuk mendapatkan kro-mosomkromosom berkualitas pada generasi berikutnya. Pemilihan kromosom berkulitas dalam seleksi dilakukan dengan memperhatikan nilai fitness. Menurut Gen dan Cheng (2000), metode seleksi yang paling dikenal ada-lah seleksi Roulette Wheel [15].

2. Crossover adalah suatu proses mengawinkan dua kromosom orang tua (pindah silang). Sebelum dilakukan crossover ditentukan probabilitas crossover $\left(P_{c}\right)$, dimana nilai $P_{c}$ mendekati 1. Crossover dillakukan jika nilai bilangan random kurang dari $P_{c \text {. }}$

3. Mutasi adalah suatu proses mengubah susunan gen da-lam suatu kromosom untuk menghindari premature kon-vergen ketika nilai fitnessnya belum optimal. Sebelum dilakukan mutasi ditentukan probabilitas mutasi $\left(P_{m}\right)$, dimana nilai $P_{m}$ mendekati nol. Mutasi dillakukan jika nilai bilangan random kurang dari $P_{m}$.

4. Elitism adalah proses pengopian individu baru agar individu yang memiliki estimasi parameter yang menghasilkan nilai fitness terbaik nilai fitness terbaik tidak hilang selama proses evolusi.

\section{Pemilihan Model Terbaik}

Pemilihan model terbaik melalui pendekatan in sample dan out sample dengan menggunakan RMSE (Root Mean Square) dan SMAPE yang dirumuskan sebagai berikut [10]. 


$$
\begin{array}{r}
R M S E=\sqrt{\frac{1}{n} \sum_{t=1}^{n}\left(Y_{t}-\hat{Y}_{t}\right)^{2}}=\sqrt{M S E} \\
S M A P E=\frac{1}{n} \sum_{i=1}^{n}\left|\frac{\left(Y_{t}-\hat{Y}_{t}\right)}{\left(Y_{t}+\hat{Y}_{t}\right) / 2}\right| x 100
\end{array}
$$

$n$ = banyaknya data

$Y_{t} \quad=$ Data actual pada waktu ke- $t$.

$\hat{Y}_{t} \quad=$ Data actual pada waktu ke- $t$.

\section{E. Curah Hujan}

Curah hujan merupakan ketinggian air hujan yang terkumpul dalam tempat yang datar, tidak menguap, tidak meresap, dan tidak mengalir. Satuan yang digunakan dalam mengukur curah hujan adalah millimeter atau mm. Berdasarkan intensitas, curah hujan dibedakan menjadi 3 yaitu hujan sedang yang berada diantara 20 dan $50 \mathrm{~mm}$ perhari, hujan lebat berada diantara 50 dan $100 \mathrm{~mm}$ perhari, dan hu-jan sangat lebat berada diatas $100 \mathrm{~mm}$ perhari [16].

\section{METODOLOGI PENELITIAN}

\section{A. Sumber Data}

Data yang digunakan dalam penelitian ini adalah data curah hujan dasarian yang berasal dari Pos pengamatan cu-rah hujan di Kedungadem Kabupaten Bojonegoro yang di-ambil di BMKG Karangploso Malang. Periode data adalah mulai bulan Januari 2000 hingga Juni 2016. Adapun data periode bulan Januari 2000 hingga Desember 2015 digu-nakan sebagai data in sample dan data bulan Januari 2016- Juni 2016 digunakan sebagai data out sample.

\section{B. Variabel Penelitian}

Berikut ini adalah variabel bebas dan variabel tak bebas yang digunakan dalam penelitian ini.

1. Variabel tak bebas $\left(Y_{t}\right)$ adalah data curah hujan dasa-rian yang dijadikan data actual/target.

2. Variabel bebas $(X)$ adalah data curah hujan dasarian pa-da waktu sebelumnya $\left(Y_{t-1}, Y_{t-2}, \ldots, Y_{t-k}\right)$.

\section{Langkah Analisis}

Langkah analisis yang digunakan dalam penelitian ini sebagai berikut.

1. Melakukan analisis statistika deskriptif dan plot data cu-rah hujan dasarian di Pos Kedungadem.

2. Analisis ARIMA, peramalan curah hujan dengan ARIMA dilakukan sesuai prosedur sebagai berikut

a. Identifikasi kestasioneran data berdasarkan plot Box-Cox dan Uji Augmented Dickey Fuller (ADF). Jika data belum stasioner dalam varians maka dilakukan transformasi dan jika belum stasioner dalam mean, maka dilakukan differencing.

b. Identifikasi model ARIMA sementara berdasarkan plot ACF dan PACF.

c. Melakukan estimasi parameter dan pengujian signifikansi parameter model. Jika parameter belum signifikan maka kembali ke langkah $2 \mathrm{~b}$.

d. Melakukan diagnostic checking pada residual yakni pengujian asumsi white noise dan normalitas resi-dual. Jika terdapat asumsi yang belum terpenuhi ma-ka kembali ke langkah $2 b$.

3. Uji non linieritas Terasvirta
4. Analisis dengan metode Support Vector Regression (SVR).

a. Menyusun model regresi dengan variable bebas $(X)$ adalah data curah hujan dasarian pada waktu sebelumnya yang diperoleh dari penguraian model ARI-MA yang memiliki parameter signifikan pada lang-kah 2 .

b. Menentukan fungsi kernel yang digunakan.

c. Menentukan range nilai parameter $C, \varepsilon$ dan $\gamma$.

d. Melakukan pemodelan dengan SVR berdasarkan pa-da range nilai parameter.

e. Melakukan pengecekan terhadap solusi yang didapatkan. Model terbaik adalah model yang memiliki nilai parameter paling optimum yang memiliki nilai error terkecil, jika kondisi ini belum terpenuhi maka proses diulang dari langkah $4 \mathrm{~d}$.

f. Melakukan peramalan berdasarkan model SVR ter-baik serta menghitung RMSE dan SMAPE.

5. Analisis dengan metode Genetic Algorithm-Support Vector Regression (GA-SVR).

a. Menyusun kromosom dengan membangkitkan 100 kromosom. Kromosom yang dibangkitkan terdiri da-ri tiga gen yang menunjukkan parameter SVR dengan menggunakan fungsi kernel RBF. Nilai inisial kromosom berasal dari nilai parameter model SVR yang telah didapatkan pada langkah 4.

b. Menentukan nilai fitness.

c. Melakukan proses seleksi roulette wheel.

d. Melakukan proses pindah silang (crossover).

e. Melakukan proses mutasi.

f. Melakukan proses elitism.

g. Melakukan pergantian populasi lama dengan gene-rasi baru dengan cara memilih kromosom terbaik berdasarkan nilai fitness.

h. Melakukan pengecekan terhadap solusi yang telah didapatkan. Solusi dikatakan telah mencapai kriteria apabila nilai fitness terbaik telah konvergen jika kon-disi ini belum terpenuhi maka proses Genetic Algo-rithm diulang dari langkah 5c.

i. Melakukan estimasi parameter dengan metode GA kemudian memasukkan parameter ke algoritma SVR dan menghitung RMSE dan SMAPE

6. Melakukan perbandingan metode ARIMA, SVR dan GASVR berdasarkan nilai RMSE dan SMAPE untuk memilih metode peramalan terbaik.

7. Melakukan forecast 6 bulan selanjutnya dengan metode terbaik dan dilakukan penyusunan kalender tanam padi berdasarkan hasil forecast yang digunakan pada tipe sa-wah tadah hujan

\section{HASIL DAN PEMBAHASAN}

\section{A. Deskripsi Curah Hujan Pos Kedungadem}

Untuk melihat kondisi curah hujan tiap bulan pada Pos Kedungadem dapat dilihat secara visual dengan boxplot pa-da Gambar 2. berikut.

Gambar 2. menunjukkan bahwa rata-rata curah hujan yang cukup tinggi terjadi pada bulan Januari, Februari, Ma-ret, April, November dan Desember. Pada bulan Juli, Agus-tus dan September memiliki rata-rata curah hujan yang ren-dah, yang mengindikasikan bahwa pada bulan tersebut ter-jadi musim 
kemarau dan musim pancaroba. Bulan Januari, Februari, Maret, April dan November terdapat outlier yang tinggi yang menunjukkan terjadinya hujan dengan intensitas yang tinggi.

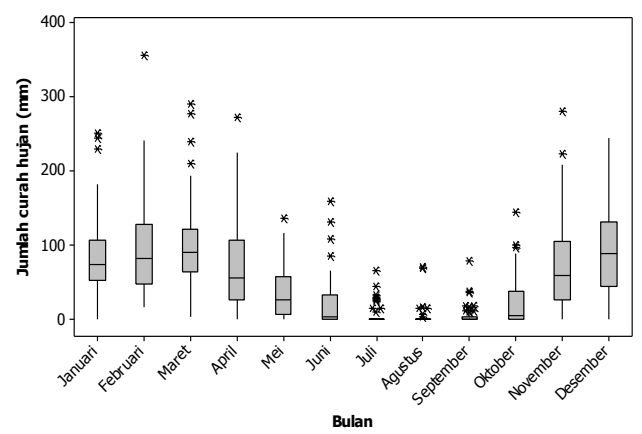

Gambar 2. Boxplot Curah Hujan Pos Kedungadem Tiap Bulan

\section{B. Peramalan Curah Hujan Menggunakan ARIMA}

Pada peramalan dengan ARIMA langkah pertama yang harus dilakukan adalah identifikasi terhadap pola data untuk mengetahui apakah data sudah stasioner terhadap varians dan mean. Dalam menggunakan ARIMA, perlu melihat ti-me series plot dari data tersebut untuk mengetahui pola dan karakteristik dari data yang ditunjukkan pada Gambar 3.(a) berikut.

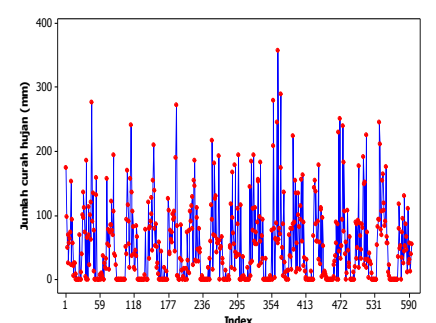

(a)

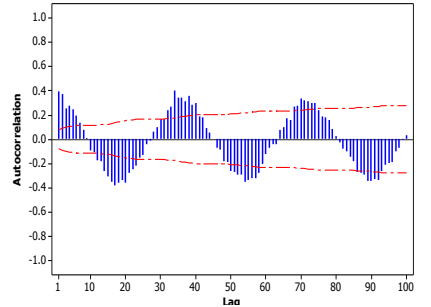

(b)
Gambar 3. Time Series Plot (a) dan Plot ACF (b) Data Curah Hujan Pos Kedungadem

Berdasarkan Gambar 3.(a) menunjukkan bahwa curah hujan dasarian di Pos Kedungadem belum stasioner ter-hadap mean dan varians karena fluktuasi antara titik satu de-ngan lainnya bervariasi. Plot ACF pada Gambar 3.(b) me-nunjukkan data memiliki pola musiman (seasonal).

Langkah selanjutnya adalah dilakukan analisis dengan melihat plot Box-Cox untuk melihat apakah data sudah stasioner dalam varians seperti pada Gambar 4.

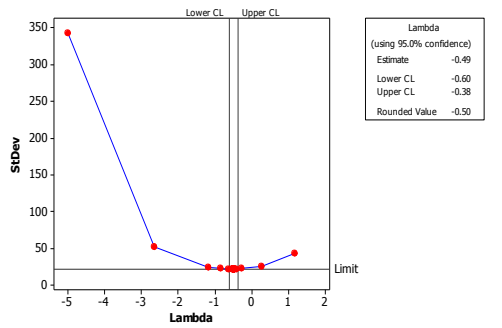

Gambar 4. Box Plot Curah Hujan Pos Kedungadem

Berdasarkan Gambar 4. diketahui bahwa data curah hu-jan dasarian di Pos Kedungadem belum stasioner terhadap varians. Hal ini ditunjukkan dengan nilai Lower $C L$ dan Up-per $C L$ yang belum melewati angka 1 atau nilai rounded va-lue $(\lambda)$ yang belum bernilai satu. Dikarenakan nilai $\lambda$ sebesar $-0,5$ maka data curah hujan akan ditransformasikan $1 / \sqrt{Y_{t}}$ untuk menstabilkan varians.

Selanjutnya dilakukan pengujian stasioneritas data terhadap mean dengan menggunakan uji Augmented Dickey Fuller (ADF). Pada uji ADF data hasil transformasi di-dapatkan $P$-value sebesar 0,01. Nilai ini menunjukkan Pva-lue kurang dari $\alpha$, sehingga tolak $H_{0}$, maka disimpulkan bahwa data transformasi sudah stasioner terhadap mean. Langkah selanjutnya dilakukan identifikasi model ARIMA sementara berdasakan pada plot ACF dan plot PACF data hasil transformasi sebagai berikut.

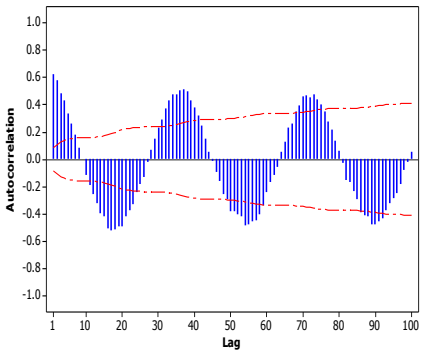

(a)

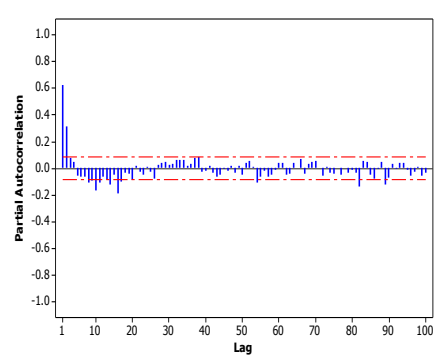

(b)
Gambar 5. Plot ACF (a) dan Plot PACF (b) Data Hasil Transformasi

Plot ACF pada Gambar 5. menunjukkan bahwa plot memiliki pola dies down. Pada plot PACF diperoleh informasi bahwa terdapat beberapa lag yang keluar dari batas significance limit yang menunjukkan bahwa lag tersebut signi-fikan. Berdasarkan plot ACF dan PACF diperoleh beberapa dugaan model ARIMA seperti pada Tabel 1.

Tabel 1. menunjukkan bahwa tidak terdapat model dugaan ARIMA yang dapat memenuhi asumsi residual white noise dan berdistribusi normal. Dikarenakan tidak ada mo-del yang memenuhi asumsi residual, maka analisis selan-jutnya akan dilakukan differencing pada data hasil trans-formasi. Pada time series plot data transformasi pada Gam-bar 3. (a) dihasilkan plot yang belum stasioner terhadap me-an serta pada Gambar 3. (b) menunjukkan bahwa pola data merupakan pola musiman. Oleh karena itu akan dilakukan differencing musiman lag 18 pada data hasil transformasi. Plot ACF dan plot PACF setelah dilakukan differencing mu-siman 18 terdapat pada Gambar 6.

Tabel 1.

Beberapa Model Dugaan ARIMA Tanpa Differencing

\begin{tabular}{cccc}
\hline Model ARIMA & $\begin{array}{c}\text { Signifikansi } \\
\text { Parameter }\end{array}$ & $\begin{array}{c}\text { Residual } \\
\text { White } \\
\text { Noise }\end{array}$ & $\begin{array}{c}\text { Normalitas } \\
\text { Residual }\end{array}$ \\
\hline ARIMA & Signifikan & $\begin{array}{c}\text { Tidak } \\
\text { Terpenuhi }\end{array}$ & $\begin{array}{c}\text { Tidak } \\
\text { normal }\end{array}$ \\
ARIMA & Tidak Signifikan & - & - \\
$([1,2,8], 0,0)$ & Signifikan & Tidak & Tidak \\
ARIMA & & Terpenuhi & normal \\
$([1,2,17], 0,0)$ & Tidak Signifikan & - & - \\
ARIMA & Signifikan & Tidak & Tidak \\
$([1,2,10,16], 0,0)$ & & Terpenuhi & normal \\
ARIMA & Tidak & Tidak \\
$([8,10], 0,0)$ & Signifikan & Terpenuhi & normal \\
ARIMA & & & \\
$([1,8], 0,0)$ & & & \\
\hline
\end{tabular}




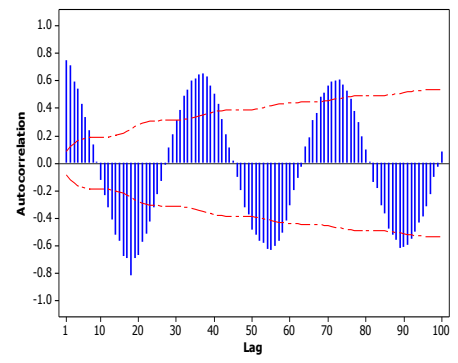

(a)

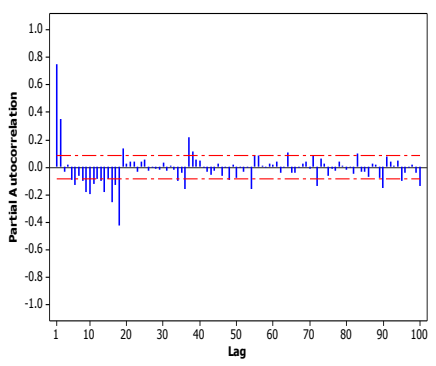

(b)
Gambar 6. Plot ACF (a) dan Plot PACF (b) Data Transformasi Setelah Differencing Musiman 18

Plot ACF pada Gambar 6.(a) memiliki pola dies down. Gambar 6.(b) menunjukkan plot PACF memiliki beberapa lag yang keluar dari batas significance limit. Berikut bebe-rapa model dugaan ARIMA berdasarkan plot ACF dan plot PACF.

Tabel 2.

Model Dugaan ARIMA dengan Differencing Musiman 18

\begin{tabular}{cccc}
\hline \hline Model ARIMA & $\begin{array}{c}\text { Signifikansi } \\
\text { Parameter }\end{array}$ & $\begin{array}{c}\text { Residual } \\
\text { White Noise }\end{array}$ & $\begin{array}{c}\text { Normalitas } \\
\text { Residual }\end{array}$ \\
\hline ARIMA & Signifikan & $\begin{array}{c}\text { Tidak } \\
\text { Terpenuhi } \\
\text { Tidak } \\
(2,0,0)(2,1,0)^{18}\end{array}$ & Normal \\
ARIMA & Signifikan & $\begin{array}{c}\text { Terpenuhi } \\
\text { Tidak }\end{array}$ & Normal \\
$([1,2,16], 0,0)(3,1,0)^{18}$ & Normal \\
ARIMA & Signifikan & Terpenuhi & \\
$([1,16,37], 0,0)(3,1,0)^{18}$ & Tidak & - & - \\
ARIMA & Signifikan & & - \\
$([1,2,6], 0,0)(3,1,1)^{18}$ & &
\end{tabular}

Tabel 2. menunjukkan tidak terdapat model ARIMA di Pos Kedungadem dengan differencing musiman 18 yang da-pat memenuhi asumsi residual yang white noise. Untuk ana-lisis selanjutnya akan digunakan differencing musiman 36 terhadap data hasil transformasi, karena diduga data curah hujan dasarian musiman selama 12 bulan. Plot ACF dan plot PACF data transformasi setelah differencing musiman 36 terdapat pada Gambar 7.

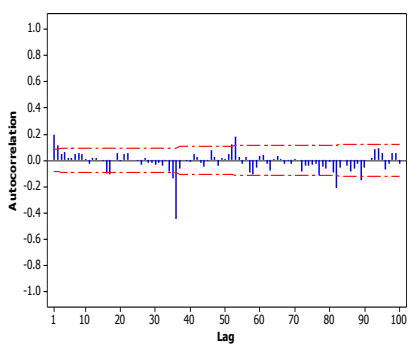

(a)

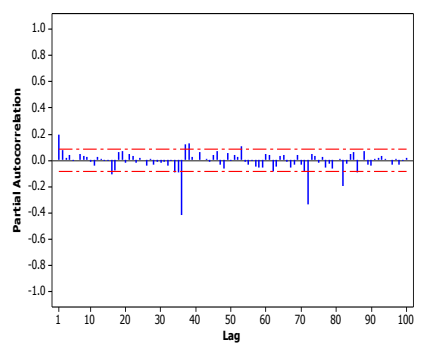

(b)
Gambar 7. Plot ACF (a) dan Plot PACF (b) Data Transformasi Setelah Differencing Musiman 36

Plot ACF dan PACF pada Gambar 6. menunjukkan terdapat beberapa lag yang keluar dari batas significance limit. Berdasarkan plot ACF dan PACF tersebut dapat ditentukan beberapa model ARIMA sementara seperti pada Tabel 3.
Tabel 3.

Model Dugaan ARIMA dengan Differencing Musiman 36

\begin{tabular}{|c|c|c|c|}
\hline Model ARIMA & $\begin{array}{c}\text { Signifikansi } \\
\text { Parameter } \\
\end{array}$ & $\begin{array}{c}\text { Residual } \\
\text { White Noise }\end{array}$ & $\begin{array}{c}\text { Normalitas } \\
\text { Residual } \\
\end{array}$ \\
\hline $\begin{array}{c}\text { ARIMA } \\
(0,0,1)(0,1,1)^{36}\end{array}$ & Signifikan & $\begin{array}{c}\text { Tidak } \\
\text { Terpenuhi }\end{array}$ & $\begin{array}{l}\text { Tidak } \\
\text { Normal }\end{array}$ \\
\hline $\begin{array}{c}\text { ARIMA } \\
(0,0,2)(0,1,1)^{36}\end{array}$ & Signifikan & Terpenuhi & $\begin{array}{l}\text { Tidak } \\
\text { Normal }\end{array}$ \\
\hline $\begin{array}{c}\text { ARIMA } \\
(1,0,1)(0,1,1)^{36}\end{array}$ & Signifikan & Terpenuhi & $\begin{array}{l}\text { Tidak } \\
\text { Normal }\end{array}$ \\
\hline $\begin{array}{c}\text { ARIMA } \\
([1,16,37], 0,0)(0,1,1)^{36}\end{array}$ & $\begin{array}{c}\text { Tidak } \\
\text { Signifikan }\end{array}$ & - & - \\
\hline $\begin{array}{c}\text { ARIMA } \\
(1,0,[1,52])(0,1,1)^{36}\end{array}$ & Signifikan & Terpenuhi & $\begin{array}{l}\text { Tidak } \\
\text { Normal }\end{array}$ \\
\hline
\end{tabular}

Dari Tabel 3. didapatkan kesimpulan bahwa dari 5 mo-del dugaan ARIMA terdapat 3 model yang memenuhi asum-si residual yang white noise. Namun, dari 3 model tersebut tidak ada yang memenuhi asumsi normalitas residual, se-hingga akan dilakukan pendeteksian outlier. Namun, hasil pemodelan dengan penambahan outlier tidak memberikan hasil residual yang berdistribusi normal, dimana $P$-value se-besar <0,0100, sehingga tolak $H_{0}$. Histogram dari residual cenderung lebih runcing (leptokurtik) serta nilai kurtosisnya bernilai positif yang menunjukkan residual model ARIMA outlier tidak berdistribusi normal. Untuk mengetahui model ARIMA yang terbaik, maka menggunakan kriteria kebaikan model in sample dan out sample yang dt pada Tabel 4.

Tabel 4.

Kriteria Kebaikan Model ARIMA

\begin{tabular}{lclr}
\hline \hline \multirow{2}{*}{ Model ARIMA } & In sample & \multicolumn{2}{c}{ Out sample } \\
\cline { 2 - 4 } & RMSE & RMSE & SMAPE \\
\hline ARIMA $(0,0,2)(0,1,1)^{36}$ & 58,0898 & 37,3650 & 45,5300 \\
ARIMA $(1,0,1)(0,1,1)^{36}$ & 57,9267 & 36,8041 & 45,6412 \\
ARIMA $(1,0,[1,52])(0,1,1)^{36}$ & 57,7702 & 33,9779 & 43,5077 \\
\hline \hline
\end{tabular}

\section{A. Peramalan Curah Hujan Menggunakan SVR}

Tahap awal sebelum masuk pada metode SVR yakni dilakukan pengujian nonlinieritas. Pengujian nonlinieritas digunakan untuk memilih fungsi kernel pada metode SVR. Dari uji Terasvirta didapatkan $P$-value sebesar $2,931.10^{-11}$, sehingga $P$-value kurang dari $\alpha(\alpha=5 \%)$ yang berarti data curah hujan dasarian di Pos Kedungadem bersifat nonlinier, oleh karena akan digunakan fungsi kernel Radial Basis Fun-ction (RBF) .

Pada peramalan dengan SVR akan menggunakan lag-lag input yang didapat dari penguraian model ARIMA pada analisis sebelumnya yang sudah memiliki parameter yang signifikan yang berjumlah 11 model. Lag input tersebut digunakan sebagai input $(X)$ pada peramalan dengan menggunakan metode SVR.

Metode SVR dengan menggunakan fungsi kernel RBF terdapat 3 parameter yaitu $C, \gamma$ dan $\varepsilon$. Namun, untuk mendapatkan hasil yang optimal parameter-parameter tersebut perlu diatur nilainya. Dari beberapa percobaan yang telah dilakukan didapatkan hasil yakni parameter $C$ yang optimal pada range 0,01-10, parameter $\varepsilon$ pada range 0,5-1 dan para-meter $\gamma$ pada range $0,05-0,1$. Selanjutnya setelah didapatkan range parameter yang optimal, maka range tersebut akan di-gunakan untuk memodelkan ARIMA yang telah memiliki parameter yang signifikan dengan metode SVR. Berikut merupakan hasil perhitungan kebaikan model dengan meng-gunakan metode SVR. 
Tabel 5.

Kriteria Kebaikan Model SVR

\begin{tabular}{cccr}
\hline \hline Model Input & $\begin{array}{c}\text { RMSE } \text { in } \\
\text { sample }\end{array}$ & $\begin{array}{c}\text { RMSE } \text { in } \\
\text { sample }\end{array}$ & $\begin{array}{c}\text { SMAPE out } \\
\text { sample }\end{array}$ \\
\hline$f\left(Y_{t-1}, Y_{t-2}\right)$ & 53,4628 & 36,2386 & 41,2593 \\
$f\left(Y_{t-1}, Y_{t-2}, Y_{t-17}\right)$ & 51,4148 & 36,8883 & 44,2713 \\
$f\left(Y_{t-8}, Y_{t-10}\right)$ & 61,3685 & 38,5177 & 40,5517 \\
$f\left(Y_{t-1}, Y_{t-8}\right)$ & 55,3269 & 38,7053 & 45,0523 \\
$f\left(Y_{t-1}, Y_{t-2}, Y_{t-18}, Y_{t-19}\right.$, & & & \\
$Y_{t-20}, Y_{t-36}, Y_{t-37}, Y_{t-38}$, & 48,0288 & 36,3635 & 40,1549 \\
$\left.Y_{t-54}, Y_{t-55}, Y_{t-56}\right)$ & & & \\
$Y_{t-1}, Y_{t-2}, Y_{t-16}, Y_{t-18}$, & & & \\
$Y_{t-19}, Y_{t-20}, Y_{t-34}, Y_{t-36}$, & & & \\
$Y_{t-37}, Y_{t-38}, Y_{t-52}, Y_{t-54}$, & 42,8774 & 44,0174 & 44,8926 \\
$Y_{t-55}, Y_{t-56}, Y_{t-70}, Y_{t-72}$, & & & \\
$Y_{t-73}, Y_{t-74}, Y_{t-88}$ & & & \\
$Y_{t-1}, Y_{t-16}, Y_{t-18}, Y_{t-19}$, & & & \\
$Y_{t-34}, Y_{t-36}, Y_{t-37}, Y_{t-52}$, & 45,1607 & 36,5999 & 39,3409 \\
$Y_{t-54}, Y_{t-55}, Y_{t-70}, Y_{t-72}$, & & & \\
$Y_{t-73}, Y_{t-88}, Y_{t-91}, Y_{t-109}$ & & & \\
$Y_{t-36}$ & 57,1360 & 32,1855 & 39,9169 \\
$Y_{t-36}$ & 57,1360 & 32,1855 & 39,9169 \\
$Y_{t-1}, Y_{t-36}, Y_{t-37}$ & 52,7867 & 41,2816 & 48,5682 \\
$Y_{t-1}, Y_{t-36}, Y_{t-37}$ & 52,7867 & 41,2816 & 48,5682 \\
\hline \hline
\end{tabular}

B. Peramalan Curah Hujan Menggunakan GA-SVR

Setelah dilakukan peramalan menggunakan SVR,maka perlu dilakukan optimasi parameter SVR agar dihasilkan peramalan yang memiliki akurasi yang lebih baik. Pada GASVR akan digunakan 5 model SVR terbaik yang dihasilkan pada analisis sebelumnya. Langkah awal pada Genetic Algorithm adalah menginisialisasi kromosom sebanyak 100, dimana nilai inisial pada kromosom didapatkan dari para-meter model SVR yang didapatkan dari analisis sebelum-nya. Kromosom yang digunakan terdiri dari tiga gen yang menunjukkan Cost $(C), \gamma$ dan $\varepsilon$. Berikut adalah ilustrasi kromosom dengan tiga gen.

\begin{tabular}{|l|c|c|c|}
\cline { 2 - 4 } \multicolumn{1}{c|}{} & Cost & $\gamma$ & $\varepsilon$ \\
\hline Kromosom & 1,01 & 0,05 & 0,5 \\
\hline
\end{tabular}

Gambar 8. Ilustrasi Kromosom Parameter SVR dengan Tiga Gen

Tabel 6.

Hasil Optimasi GA pada Model SVR

\begin{tabular}{crrr}
\hline \hline Model & $\begin{array}{c}\text { RMSE } \\
\text { in sample }\end{array}$ & $\begin{array}{c}\text { RMSE } \\
\text { out sample }\end{array}$ & $\begin{array}{c}\text { SMAPE } \text { out } \\
\text { sample }\end{array}$ \\
\hline$f\left(Y_{t-1}, Y_{t-2}\right)$ & 53,4059 & 36,2795 & 41,1911 \\
$f\left(Y_{t-1}, Y_{t-2}, Y_{t-17}\right)$ & 51,1191 & 36,3896 & 43,5163 \\
$f\left(Y_{t-1}, Y_{t-2}, Y_{t-18}, Y_{t-19}\right.$, & & & \\
$Y_{t-20}, Y_{t-36}, Y_{t-37}, Y_{t-38}$, & 47,7961 & 36,1657 & 40,4743 \\
$\left.Y_{t-54}, Y_{t-55}, Y_{t-56}\right)$ & & & \\
$f\left(Y_{t-1}, Y_{t-2}, Y_{t-16}, Y_{t-18}\right.$, & & & \\
$Y_{t-19}, Y_{t-20}, Y_{t-34}, Y_{t-36}$, & & & \\
$Y_{t-37}, Y_{t-38}, Y_{t-52}, Y_{t-54}$, & 42,8520 & 41,1462 & \\
$Y_{t-55}, Y_{t-56}, Y_{t-70}, Y_{t-72}$, & & & \\
$\left.Y_{t-73}, Y_{t-74}, Y_{t-88}\right)$ & & & \\
$f\left(Y_{t-1}, Y_{t-16}, Y_{t-18}, Y_{t-19}\right.$, & & & \\
$Y_{t-34}, Y_{t-36}, Y_{t-37}, Y_{t-52}$, & 42,9440 & 35,2800 & \\
$Y_{t-54}, Y_{t-55}, Y_{t-70}, Y_{t-72}$, & & & \\
$\left.Y_{t-73}, Y_{t-88}, Y_{t-91}, Y_{t-109}\right)$ & & & \\
\hline \hline
\end{tabular}

Nilai fitness yang digunakan pada penelitian ini adalah nilai kesalahan dalam peramalan yaitu RMSE. Nilai fitness merupakan acuan dalam tahapan Genetic Algorithm seperti melakukan proses seleksi, pindah silang (crossover), mutasi dan elitism sehingga didapatkan nilai fitness terbaik. Fungsi objektif yang ingin dicapai pada penelitian ini adalah untuk meminimumkan nilai RMSE pada pada model SVR. Penelitian ini akan menggunakan probabilitas crossover $\left(P_{c}\right)$ sebesar 0,8 dan probabilitas mutasi $\left(P_{m}\right)$ sebesar 0,01 . Tabel 6 . menunjukkan hasil optimasi 5 model SVR terbaik yang didapatkan pada langkah sebelumnya.

\section{Perbandingan Model Terbaik}

Hasil perbandingan model terbaik dari masing-masing metode peramalan ditunjukkan pada Tabel 7 .

Tabel 7.

Perbandingan Model Terbaik

\begin{tabular}{ccccr}
\hline Metode & Model & $\begin{array}{c}\text { RMSE } \\
\text { in sample }\end{array}$ & $\begin{array}{c}\text { RMSE } \\
\text { out sample }\end{array}$ & $\begin{array}{c}\text { SMAPE } \\
\text { out sample }\end{array}$ \\
\hline ARIMA & ARIMA & & & \\
& $(1,0,[1,52])$ & 57,7702 & 33,9779 & 43,5077 \\
& $(0,1,1)^{36}$ & & & \\
& $f\left(Y_{t-1}, Y_{t-16}\right.$, & & & \\
& $Y_{t-18}, Y_{t-19}$, & & & \\
& $Y_{t-34}, Y_{t-36}$, & & & \\
SVR & $Y_{t-37}, Y_{t-52}$, & 45,1607 & 36,5999 & 39,3409 \\
& $Y_{t-54}, Y_{t-55}$, & & & \\
& $Y_{t-70}, Y_{t-72}$, & & & \\
& $Y_{t-73}, Y_{t-88}$, & & & \\
& $\left.Y_{t-91}, Y_{t-109}\right)$ & & & \\
& $f\left(Y_{t-1}, Y_{t-16}\right.$, & & & \\
& $Y_{t-18}, Y_{t-19}$, & & & \\
& $Y_{t-34}, Y_{t-36}$, & & & \\
GA-SVR & $Y_{t-37}, Y_{t-52}$, & 42,9440 & 35,2800 & \\
& $Y_{t-54}, Y_{t-55}$, & & & \\
& $Y_{t-70}, Y_{t-72}$, & & & \\
& $Y_{t-73}, Y_{t-88}$, & & & \\
& $\left.Y_{t-91}, Y_{t-109}\right)$ & & & \\
\hline \hline
\end{tabular}

Tabel 7. menunjukkan bahwa model terbaik untuk meramalkan curah hujan Pos Kedungadem adalah model input $f\left(Y_{t-1}, Y_{t-16}, Y_{t-18}, Y_{t-19}, Y_{t-34}, Y_{t-36}, Y_{t-37}, Y_{t-52}, Y_{t-54}, Y_{t-55}\right.$, $\left.Y_{t-70}, Y_{t-72}, Y_{t-73}, Y_{t-88}, Y_{t-91}, Y_{t-109}\right)$ yang di-dapatkan dari metode GA-SVR. Model ini memiliki kete-patan akurasi yang paling tinggi dibandingkan metode lain-nya. Tabel 8. menunjukkan forecast curah hujan 18 periode selanjutnya yakni pada bulan Juli 2016 sampai dengan De-sember 2016 menggunakan metode GA-SVR pada Pos Ke-dungadem.

Tabel 8.

Forecast 6 bulan Selanjutnya

\begin{tabular}{clr|ccr}
\hline \hline No & Bulan & Forecast & No & Bulan & Forecast \\
\hline 1 & Juli & 36,2111 & 10 & Oktober & 13,2873 \\
2 & Juli & 22,6570 & 11 & Oktober & 20,3639 \\
3 & Juli & 26,7335 & 12 & Oktober & 29,5119 \\
4 & Agustus & 13,8875 & 13 & November & 44,3715 \\
5 & Agustus & 23,2287 & 14 & November & 67,2780 \\
6 & Agustus & 19,4592 & 15 & November & 95,2588 \\
7 & September & 12,0215 & 16 & Desember & 74,9463 \\
8 & September & 21,9582 & 17 & Desember & 72,3197 \\
9 & September & 17,3114 & 18 & Desember & 55,2144 \\
\hline \hline
\end{tabular}

D. Kalender Tanam Padi Bulan Juli 2016-Desember 2016

Hasil forecast curah hujan pada Tabel 8. menunjukkan bahwa curah hujan selama 6 bulan tersebut antara 50-100 mm dan kurang dari $50 \mathrm{~mm}$. Susunan kalender tanam padi untuk wilayah Kedungadem Kabupaten Bojonegoro bulan Juli 2016 hingga Desember 2016 terdapat pada Gambar 9. 
Berdasarkan Gambar 9. didapatkan informasi yaitu kebutuhan air untuk penanaman padi sawah sepanjang bulan Juli 2016 - Desember 2016 tidak dapat terpenuhi, karena penanaman padi sawah membutuhkan air rata-rata $145 \mathrm{~mm}$ pada musim hujan [17], sehingga penanaman padi harus di-bantu dengan pengairan dan tidak mengandalkan turunnya hujan. Pada bulan Juli hingga Oktober petani dapat meng-ganti padi dengan palawija, dikarenakan palawija mem-butuhkan air yang lebih sedikit sekitar $50 \mathrm{~mm}$ pada musim kemarau [17].

\begin{tabular}{|l|l|l|l|l|l|l|l|l|l|l|l|l|l|l|l|l|l|}
\hline \multicolumn{3}{|c|}{ Juli } & \multicolumn{3}{|c|}{ Agustus } & \multicolumn{3}{|c|}{ September } & \multicolumn{3}{c|}{ Oktober } & \multicolumn{3}{c|}{ November } & \multicolumn{3}{|c|}{ Desember } \\
\hline 1 & 2 & 3 & 1 & 2 & 3 & 1 & 2 & 3 & 1 & 2 & 3 & 1 & 2 & 3 & 1 & 2 & 3 \\
\hline & & & & & & & & & & & & & & & & & \\
\hline \multicolumn{11}{|c|}{ Palawija } & \multicolumn{11}{c|}{$\begin{array}{c}\text { Tanam padi } \\
\text { dengan bantuan } \\
\text { pengairan }\end{array}$} \\
\hline
\end{tabular}

Gambar 9. Kalender Tanam Padi Periode Juli 2016-Desember 2016

\section{KESIMPULAN DAN SARAN}

\section{A. Kesimpulan}

Berdasarkan hasil analisis yang sudah dilakukan, maka didapatkan beberapa kesimpulan untuk menjawab tujuan yang telah ditetapkan sebagai berikut.

1. Berdasarkan RMSE dan SMAPE maka peramalan de-ngan menggunakan GA-SVR menghasilkan akurasi pe-ramalan yang lebih baik.

2. Hasil kalender tanam padi untuk tipe sawah tadah hujan menunjukkan pada bulan Juli hingga Desember 2016 kebutuhan air untuk penanaman padi sawah tidak dapat dipenuhi. Petani dapat mengganti dengan menanam palawija atau jika tetap dilakukan tanam padi, maka pe-tani dan pemerintah harus memastikan tersedianya ca-dangan air.

\section{B. Saran}

Saran untuk penelitian selanjutnya adalah dapat di-gunakan metode yang bisa memperhatikan adanya pengaruh dari variabel lain. Dalam metode SVR dapat dicoba meng-gunakan input dari data asli atau input lain tanpa melalui metode ARIMA, serta dapat digunakan pilihan range para-meter yang lain agar didapatkan peramalan yang lebih baik

\section{DAFTAR PUSTAKA}

[1] Badan Pusat Statistik. 2014. Bojonegoro Dalam Angka Tahun 2014. Bojonegoro: BPS

[2] Badan Meteorologi, Klimatologi dan Geofisika (BMKG). 2016. Tentang Meteorologi?

http://meteojuanda.info/index.php?option=com_content\&view=article \&id=3 6\&Itemid=34. Diakses pada tanggal 12 November 2016.

[3] Badan Pusat Statistik. 2016. Bojonegoro Dalam Angka Tahun 2016. Bojonegoro : BPS.

[4] Zhang, G. 2003. Time Series Forecasting Using a Hybrid ARIMA and Neural Network Model. Journal Neurocomputing 50:159-175.

[5] Hong, W C., dkk. 2011. Forecasting Urban Traffic Flow by SVR with continuous ACO. Appl. Math. Model.vol. 35, no. 3, pp. 1282-1291.

[6] Zhao, W., Tao, T., dan Zio, E. 2015. System Reliability Prediction by Support Vector Regression with Analytic Selection and Genetic Algorithm Parameters Selection. Applied Soft Computing, 30, 792-802.

[7] Gunn, S.1998. Support Vector Machines for Classification. Technical Report.Southampton: University of Southampton.

[8] Msiza, I. S., Nelwamondo F. V. dan Marwala T., 2008. Water Demand Prediction using Artificial Neural Networks and Support Vector Regression. Journal of Computers, Vol. 3, No. 11, November 2008.
[9] Gu, J., Zhu, M, dan Jiang L. 2011. Housing Price Forecasting Based on Genetic Algorithm and Support Vector Machine. Expert System with Application 3383-3386.

[10] Wei, W.,W.,S. 2006. Time Series Analysis Univariate and Multivariate Method 2nd Editions. New York: Addison Wesley Publishing Company, Inc.

[11] Cryer, J. D. dan Chan, K. 2008. Time Series Analysis with Application in R, 2nd Edition. New York: Springer.

[12] Bowerman, B., O'Connell, R. T., dan Koehler, A. B. 2004. Foreasting, Time Series, and Regression: An Applied Approach. Boston: Cengage Learning, Inc.

[13] Daniel, W. W. 1989. Statistika Nonparametrik Terapan. Alih Bahasa: Alex Tri Kuncoro. Jakarta:PT Gramedia.

[14] Putri, T. 2016. Peramalan Return Saham Bank Central Asia Menggunakan Self Exciting Threshold Autoregressive- Genetic Algorithm. Penelitian. Surabaya: Institut Teknologi Sepuluh Nopember.

[15] Yuliani, W., Irhamah dan Prastyo D D. 2014. Penaksiran Parameter Model ARIMA dengan Menggunakan Genetic Algorithm. Penelitian. Surabaya: Institut Teknologi Sepuluh Nopember.

[16] Suriadikusumah, A. 2007. Analisis Curah Hujan Perhitungan \& Penggunaannya. Bandung: Rakayasa Sains.

[17] Oldeman, L. R. 1980. The Agroclimate Classification of Rice Growing Enviroment in Indonesia. Philiphinas: IRRI. 